\title{
CONSUMER BRAND LOVE FOR LUXURY BRANDS IN INDIA
}

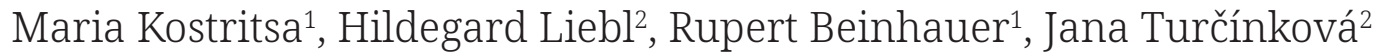 \\ ${ }^{1}$ Institute of International Management, FH-Joanneum, Eggenberger Allee 11, 8020 Graz, Austria \\ 2 Faculty of Business and Economics, Mendel University in Brno, Zemědělská 1, 61300 Brno, Czech Republic
}

Link to this article: https://doi.org/10.11118/actaun202068010189

Received: 25. 7. 2019, Accepted: 28. 12. 2019

To cite this article: KOSTRITSA MARIA, LIEBL HILDEGARD, BEINHAUER RUPERT, TURČÍNKOVÁ JANA. 2020. Consumer Brand Love for Luxury Brands in India. Acta Universitatis Agriculturae et Silviculturae Mendelianae Brunensis, 68(1): 189-197.

\begin{abstract}
To establish brand love as the strongest bond between consumer and brand is a valuable target: different approaches explaining the antecedents of brand love can be found in literature. Concerning the outcome, most authors conclude on some positive relations towards brand loyalty, the willingness to pay a price premium and spreading positive word of mouth. Because of the growing importance of the luxury industry especially in emerging markets, this study investigates on the existence of brand love for luxury brands in the Indian market where so far, no quantitative research about brand love for luxury goods exists. The objective of this study is to research if Indian luxury brands are subject of brand love, and in case of existence, what kind of outcome is related to this phenomina. Data was collected via online questionnaire in May and June 2018. The sample was a non-probability convenience sample $(n=164)$ from Indian consumers. Relying on a modified model created by Carroll and Ahuvia (2006) a correlation analyses proved the relations between brand love, self-expressive brands, brand loyalty, positive word of mouth and the willingness to pay a price premium. An exploratory factor analyses which was carried out later suggests the adoption of a new three factor structure of brand love for future research in the context of high hedonic product categories.
\end{abstract}

Keywords: brand love, self-expressive brands, brand loyalty, willingness to pay a price premium

\section{INTRODUCTION}

The market for luxury products has been growing steadily for the last years. According to Deloitte Global (Deloitte Global, n.d.) from 2015 to 2017, the compound annual growth rate in the luxury goods market worldwide was 5.3\%, the aggregate luxury goods sales were at US\$ 247 billion. Especially emerging markets like India are on the rise. Roughly $10 \%$ of the Indian GDP and 18\% of the working population depended on the retail sector and in April 2018 the size of the luxury market was US $\$ 18.5$ billion. The composition of the Indian luxury market looks as follows: personal luxury goods, fine food, luxury cars and yachts, fine wine and spirits, luxury art and luxury services like luxury hospitality. The market is dominated by jewelry, apparel and luxury travel (17\%, 16\% and 15\% of total household expenditures of most affluent households). Indian luxury consumers differentiate from others in several aspects: the typical luxury consumer is price sensitive and always looking for good deals because bargaining is part of Indian culture. They tend to collect information before buying. Consumer behavior depends on product category. For apparel and accessories 64\% of consumers claim to do impulsive purchases. Within the art and painting category $32 \%$ of consumers claim to do a prior research. Brand attributes like logos and brand image have significant effects on the purchasing decision because they communicate status and value of the individual. For the Indian consumers the product quality is valued but the 
main value is coming from the perception and image of the brand. 32\% of high-end consumers stated in 2016 that the brand is the only reason for luxury goods purchases. So for India luxury goods need to communicate financial and social status (Kotak Wealth Management, 2016).

Building a strong relationship from the luxury brand towards the consumer is a valuable target within brand management. Relationships in marketing are dynamic and complex (Fetscherin, Mark, 2014). It is worth to build a relationship, as fewer shifts in consumer preferences happen when the connection is strong. This complex and longterm meaningful relationship between a consumer and the brand is named brand love which includes multitudinous interrelated processes (Batra et al., 2012). So brand love is the highest level of binding or affection a consumer can form with a brand (Albert and Merunka, 2013) and plays an important role in brand management for predicting and understanding consumer behavior.

Consumers are less sensitive on external forces influencing the brand, like competitive activities, technological developments or economic, social and political changes when the relationship towards a brand is strong. With a strong brand image and brand value in the minds of consumers, luxury brands can inspire positive word of mouth and brand loyalty. Furthermore, it stimulates consumers' willingness to pay a higher price for the products and services that demonstrate perceived superiority. Brand love is more than a 'simple' emotion: representing a meaningful and often long relationship between the consumer and the brand it covers affective and cognitive processes as well as behavior aspects (Albert and Merunka, 2013) and therefore is of highest importance to understand and to predict consumer behavior. Brand love was mostly tested in the United States and only a few studies were conducted elsewhere, e.g. in France (Albert et al., 2008) or in Brazil (Fetscherin and Mark, 2014). Some qualitative studies exist for India (Sarkar, 2014; Sternberg, 1986;), but quantitative results have not been collected. Quantitative research on post-consumption behavior in connection with brand love can add a new perspective about the Indian market. This is especially important for Indian luxury brands: brand love is increasing the willingness to pay a price premium. Taking in account, that bargaining is part of the Indian culture (Kotak Wealth Management, 2016) it is interesting to investigate if brand love may trigger this impact.

In our paper, the following research questions are elaborated: 'What kind of effects of self-expressive luxury brands on brand love can be shown in India?' and 'What are impacts of brand love for luxury brands in India?'

\section{MATERIALS AND METHODS}

The term 'love' in connection with brand love shows substantial body of research in branding literature, reflecting the importance of emotions. The most important theories of brand love will be discussed shortly: The first model goes back to the analogy of interpersonal love theory by Sternberg in 1986. He defined love relationships, depending on the dominance of three dimensions, namely (1) intimacy (the feeling of closeness), (2) passion and (3) decision/commitment (Sternberg, 1986). Sternberg's theory was adapted by Shimp and Madden, often called the pioneers of band love (Carroll and Ahuvia, 2006). The three components were further developed: (1) intimacy towards liking, (2) passion into yearning and (3) decision/ commitment remained the same (Shimp and Madden, 1988). Sternberg uses the analogy of a geometric triangle in order to show the 'amount' of love (Sternberg, 1986), Shimp and Madden adapted this analogy by formulating 8 possible relationships, depending on the existence of liking, yearning and decision/commitment. So if none of the components exists, the relationship style is 'nonliking', whereas when every component counts Shimp and Madden (1988) talk about 'loyalty'. Between these two other relationships styles, namely liking, infatuation, functionalism, inhibited desire, utilitarism and succumbed desire can be found, depending on the existence of the three components. Criticism on their theory refers to the issue that interpersonal relations cannot be transferred to consumer - object relations based on an analogy (Aggarwal, 2004).

Other brand love models based on interpersonal theories of love where developed by Whang et al. (2004) focusing on 'Mania' (which reflects a possessive love style), 'Agape' (altruistic love, selfless) and 'Eros' (passionate and romantic love).

Another model focusing on 5 factors was developed by Kamat \& Parulekar (2007), where friendship, contentment, admiration, commitment and yearning were created by their construct which was developed by qualitative in-depth interviews. These 5 items where confirmed by quantitative research later on (Fröhling, 2017).

Other interpersonal love theory based concepts come from Bergkvist/Bech-Larsen and Langner/ Kühn in 2010. Rossiter (2012) created the C-OAR-SE measurement to differentiate brand love from brand liking by focusing on 2 components only, namely deep affection and separation anxiety.

Carroll and Ahuvia (2006) introduced a new model being independent on interpersonal love theories. Their model is based on Ahuvias' model (see Ahuvia, 2005) of the extended self, exploring the relation between the consumer identity and loved objects. They experienced that brands, which reflect more the inner self of a consumer, are more likely to be loved, because they strengthen the 
social self. Also, self-expression was integrated as important factor of brand love. Their measurement of brand love is built on 5 characteristics of brand love: (1) positive evaluation of the brand, (2) positive emotion in response to the brand, (3) attachment, (4) passion and (5) declaration of love for the brand (Carroll and Ahuvia, 2006). This model is most often used for further and more recent studies (e.g. Baena, 2016; Hegner et al., 2017; Huang, 2017; Ismael and Spinelli, 2012; Karjahuoto et al., 2016; Pinto Borges et al., 2016), although the single components were not further specified and the origination of the construct is not clear-cut (Fröhling, 2017). Nevertheless, this model is most often used in literature for measuring brand love.

A more complex model was defined by Albert, Merunka and Valette-Florence in 2008/2009: building on qualitative and quantitative research they developed a new brand love model, focusing on 11 dimensions: (1) passion (like Shimp and Madden and Carroll and Ahuvia) (2) duration of the relationship, (3) self-congruity, (4) dreams (should reflect the dominant role of brands for consumers) (5) memories (e.g. from childhood or family rituals), (6) pleasure (pure positive emotion), (7) attraction, (8) uniqueness, (9) beauty, (10) trust and (11) declaration of affect (Albert et al., 2008). Albert et al., (2009) further developed their model by introducing basic dimensions affection and passion as second order factors.

One of the most often cited models in literature is the brand love construct created by Batra, Ahuvia and Bagozzi in 2012 (Moussa, 2015). The authors built a model focusing on 7 dimensions: (1) self-brand integration (partly comparable with the factor self-congruity by Albert et al. but also including integration into ideal self), (2) passion driven behaviors (like the willingness to invest resources or the desire to use), (3) positive emotional connection (building on emotional attachment, intuitive fit and positive affect), (4) long-term relationship, (5) positive overall attitude valence (satisfaction), (6) attitude strength (e.g. frequent thoughts), and (7) anticipated separation distress (negative emotions like fear) (Batra et al., 2012).

Fröhling (2017) created the most recent model of brand love, building on the S-O-R model (stimulusorganism-response, consumer behavior). The brand reflects a stimulus (with functional, emotional and symbolic functions) and brand love the organism dimension.

The above-mentioned brand love theories reflect a great variety and difference within the models, especially in terms of antecedents. What they all have in common: (1) almost every construct refers to the following consequences of brand love: willingness to pay a price premium, loyalty and willingness to forgive the brand failures; (2) positive emotions play an important role within this consumer-brand love relationships, but also other factors aside of emotions are used to explain the different brand love models, although the word 'love' has a strong emotional connotation.

So especially self-expressive brands, which are addressing values or characteristics desired by the consumer, can trigger the desired post consumption behavior (including paying a price premium) by increasing brand love (Albert et al., 2008; Carroll and Ahuvia, 2006). Brands with clear hedonic attribute provide passionate or emotional connection. Wallace et al. (2017) stated that the closeness of the brand identity towards the consumers' identity has a positive impact on brand love (Wallace et al., 2017). Already in 1990s Fournier discussed the self-connection between the consumers and the brand through shared values, concerns, themes and attributes (Fournier, 1998). Consumers sense the brand is something they can identify with (Sarkar, 2014) and brands serve as a purpose of self-presentation and expression by becoming an extension of one's personality (Wallace et al., 2014). A brand can also function as a social integration tool: When the brand is used by a reference group consumer tend to have a stronger connection towards the brand (Albert and Merunka, 2013).

The current research examines brand love as an outcome variable as well as a predictor and reflects on the dependence of brand love on self-expressive brands. Furthermore, the importance of brand love being a determinant for positive word of mouth (WOM), the willingness to pay a price premium and for brand loyalty is investigated.

The above mentioned arguments show that selfexpressive brands are proposed to be an antecedent of brand love, and it is also claimed to be critical in relation to the development of love-based relationships with brands (Albert and Merunka, 2013). Some authors claim that the congruity between the brand identity and the consumers' selfconcept is not relevant, because brand love is not dependent on self-expressive brands (e.g. Whang et al., 2004). This makes it important to explore the accuracy of the assumption that a self-expressive brand is directly related to brand love.

\section{H1: Self-expressiveness of brands has a positive effect} on brand love.

As because it is argued that self-expressive brands (which represent the consumers' desired and actual self) have an effect on favored post-consumption behaviors (Albert et al., 2008; Carroll and Ahuvia, 2006), the following hypothesis are taken into account:

H2: Self-expressiveness of brands has a positive effect on brand loyalty.

H3: Self-expressiveness of brands has a positive effect on positive word of mouth.

H4: Self-expressiveness of brands has a positive effect on the willingness to pay a price premium. 
Concerning brand loyalty Yoo and Donthu stated in 2001 that the consumer's predisposition to a certain brand is shown within the purchasing possibility when alternatives are presented (Yoo et al., 2001). The commitment presented with brand loyalty is a component of brand love. It can be characterized as the desire to continue a relationship in the long term (Thomson et al., 2005; Garg et al., 2015, p. 182). The connection between commitment, passion and brand loyalty shows a possible relation between brand love and brand loyalty (Fetscherin and Mark, 2014). Brand loyalty can be a possible outcome of brand love (Albert et al., 2009; Carroll and Ahuvia, 2006; Thomson et al., 2005).

H5: Indian luxury consumers who feel greater brand love are more brand loyal.

Brand love also stimulates different forms of brand engagement, it does not only incite consumer attitudes towards the brand, such as brand loyalty (Wallace et al., 2014). One of the most common forms of brand engagement is positive word of mouth, which can be defined as "informal communications between private parties concerning evaluations of goods and services" (Anderson, 1998, p. 6). The link between brand passion and positive WOM is also confirmed in more recent studies. (Albert and Merunka, 2013; Fetscherin and Mark, 2014).

H6: Indian luxury consumers who feel greater brand love engage in more positive word of mouth.
Furthermore, there is evidence that brand love may lead consumers to put the brand's interest in front of their own for maintaining their relationships (Batra et al., 2012) The nature of consumer-brand-relationships may influence the willingness to pay a price premium because of affective brand commitment, rather than the functional benefits of a brand (Albert and Merunka, 2013).

H7: Indian luxury consumers who feel greater brand love are more willing to pay a price premium.

The Fig. 1 summarizes the research model.

The research followed a descriptive, quantitative research design based on the conceptual model of Carroll and Ahuvia (2006). The original model was tested on 334 respondents from the United States across various brands of packaged goods. The research is extended by adding new variables in order to better explain the phenomenon and address specific challenges. The willingness to pay a price premium is included as an additional outcome and consequently hedonism is excluded because of the hedonic nature of luxury brands. Tab. I represents the origination of the different constructs.

All five constructs include multiple variables which were pre-tested and tested on a 7-point Likert scale, where the left most anchor signifies strong disagreement with a statement, the right most anchor reflects strong agreement, and a middle point served as a neutral response.

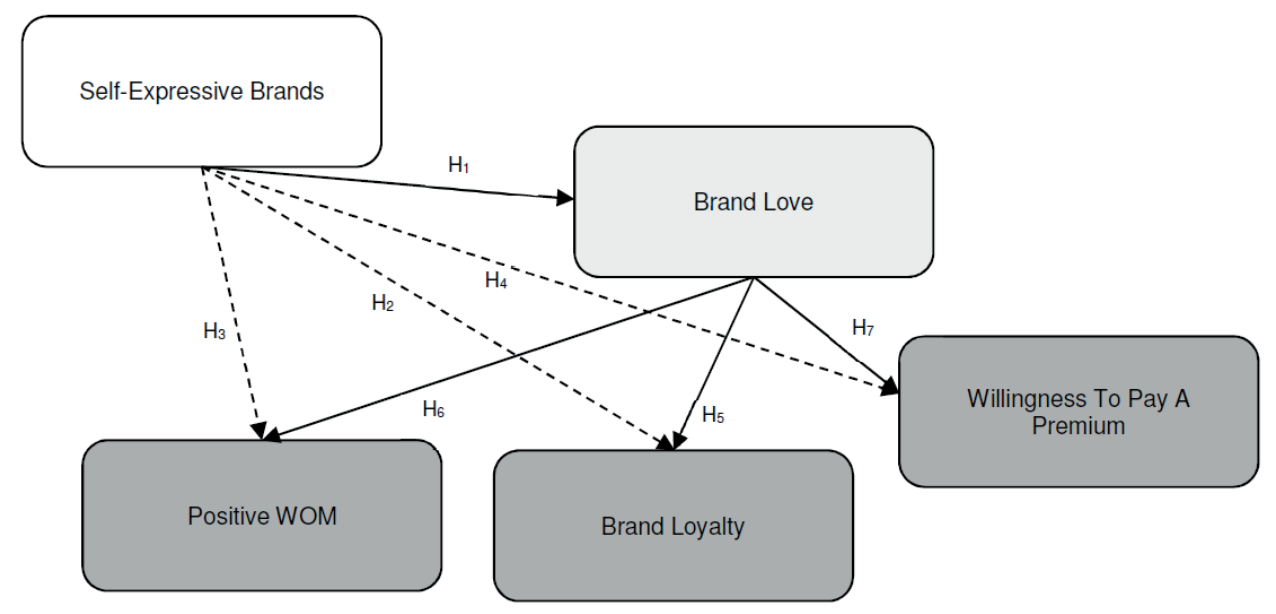

1: Research Framework

I: Origin of constructs

\begin{tabular}{lcl}
\hline \multicolumn{1}{c}{ Construct } & Number of Items & \multicolumn{1}{c}{ Source } \\
\hline Brand Love & 5 & Carroll and Ahuvia, 2006 \\
Self-expressive Brand & 7 & Carroll and Ahuvia, 2006 \\
Brand Loyalty & 4 & Carroll and Ahuvia, 2006; Yoo and Donthu, 2001 \\
Positive Word of Mouth & 4 & Carroll and Ahuvia, 2006 \\
Willingness to Pay a Price Premium & 3 & Netemeyer et al., 2004 \\
\hline
\end{tabular}




\begin{tabular}{|c|c|c|c|}
\hline \multicolumn{2}{|l|}{ Construct } & Item & Code \\
\hline \multirow{6}{*}{\multicolumn{2}{|c|}{ Brand Love }} & This brand makes me feel good. & BL1 \\
\hline & & I love this brand! & BL2 \\
\hline & & I have no particular feelings about this brand (negatively framed). & BL3 \\
\hline & & I have no particular feelings about this brand (positively framed). & BL3_r \\
\hline & & I am passionate about this brand. & BL4 \\
\hline & & I am very attracted to this brand. & BL5 \\
\hline \multirow{4}{*}{\multicolumn{2}{|c|}{ Brand Loyalty }} & When I go shopping, I don't even notice competing brands. & LTY1 \\
\hline & & I consider myself to be loyal to this brand. & LTY2 \\
\hline & & When shopping, this brand would be my first choice. & LTY3 \\
\hline & & I will not buy other brands if this brand is available at the store. & LTY4 \\
\hline \multirow{4}{*}{\multicolumn{2}{|c|}{ Positive Word of Mouth }} & I have recommended this brand to lots of people. & WOM1 \\
\hline & & I talked up this brand with my friends. & WOM2 \\
\hline & & I try to spread the good-word about this brand. & WOM3 \\
\hline & & I give this brand tons of positive word of mouth advertising. & WOM4 \\
\hline \multirow{7}{*}{ Self-Expressive Brand } & \multirow{3}{*}{ Inner Self } & This brand symbolizes the kind of person I really am inside. & EXI1 \\
\hline & & This brand reflects my personality. & EXI1 \\
\hline & & This brand is an extension of my inner self. & EXI1 \\
\hline & \multirow{4}{*}{ SociaL Self } & This brand contributes to my image. & EXS1 \\
\hline & & This brand adds to a social role play. & EXS2 \\
\hline & & This brand has a positive impact on what others think of me. & EXS3 \\
\hline & & This brand improves the way society views me. & EXS4 \\
\hline \multirow{3}{*}{\multicolumn{2}{|c|}{ Willingness to Pay a Price Premium }} & $\begin{array}{l}\text { The price of the products by this brand would have to go up quite } \\
\text { a bit before I would switch to another brand. }\end{array}$ & PRE1 \\
\hline & & $\begin{array}{l}\text { I am willing to pay a higher price for products by this brand } \\
\text { than for products by other brands. }\end{array}$ & PRE1 \\
\hline & & $\begin{array}{l}\text { I am willing to pay a lot more for this brand thna other brands } \\
\text { of the same product category. }\end{array}$ & PRE1 \\
\hline
\end{tabular}

The construct of positive WOM was entirely taken from the original research, the other three constructs from Carroll and Ahuvia (2006) were to some extent modified by either replacing items with more suitable ones from other sources or by shortening measures to eliminate redundancies. The ten-item brand love scale was reduced to 5 items; the construct of selfexpressive brands was reduced from original eight to seven items. The adjustments are the results of a small-scale pre-test consisting of eight people, in total the 30 items of the questionnaire were reduced to 23. As an additional result a field was included where participants could enter brand names they were thinking about. It was later interesting to learn what respondents consider luxury brands. The construct of willingness to pay a price premium is not included in the original study; as because India is an emerging market this construct offers a deeper insight into price sensitivity within Indian luxury consumption.

The target group were people originated from India with internet access, who claimed the existence of a self-reported emotional attachment to one or more luxury brands. The sample was a non-probability convenience sample; data collection was done by convenience sampling with the use of snowball effects using social media channels. The sample size was calculated ${ }^{1}$ using the power analysis introduced by Cohen (2013), indicating a sample size of at least 115 respondents. An online questionnaire was developed by using the online survey platform QuestionPro. As the target population consists of English-speaking persons, the survey was administered in English which eliminates possibilities of mistranslation 
because the original items were developed in English. The survey started on May 24, 2018 and ended on June 29, 2018, the result was 164 completed responses from Indian consumers. Mostly from participants in the age group 18-34 (36 participants between 18 and 24; 93 participants between 25 and 34; 35 older), who are using social media on a daily basis. Data included a good mix of gender (72 female, 89 male participants). The survey was started 273 times and the response rate accounts $61.9 \%$. The research was carried out by Maria Kostritsa as a part of her Master Thesis under the supervision of Hildegard Liebl. Tab. II presents the coding of the items and shows the construct.

\begin{tabular}{|c|c|c|c|c|c|c|}
\hline & & 1 & 2 & 3 & 4 & 5 \\
\hline 1 & Self-Expressive Brands & 1,000 & & & & \\
\hline 2 & Brand Love & $.604^{* *}$ & 1,000 & & & \\
\hline 3 & Brans Loyalty & $.522^{* *}$ & $.521^{* *}$ & 1,000 & & \\
\hline 4 & Positive Word of Mouth & $.562^{* *}$ & $.650^{* *}$ & $.526^{* *}$ & 1,000 & \\
\hline 5 & Willingness to Pay a Premium & $.562^{* *}$ & $.450^{* *}$ & $.615^{* *}$ & $.446^{* *}$ & 1,000 \\
\hline
\end{tabular}

** Correlation is significant at the 0.01 level (1-tailed).

Notes: $\mathrm{N}=164$ for all variables except Willingness to Pay Premium for which $\mathrm{N}=163$

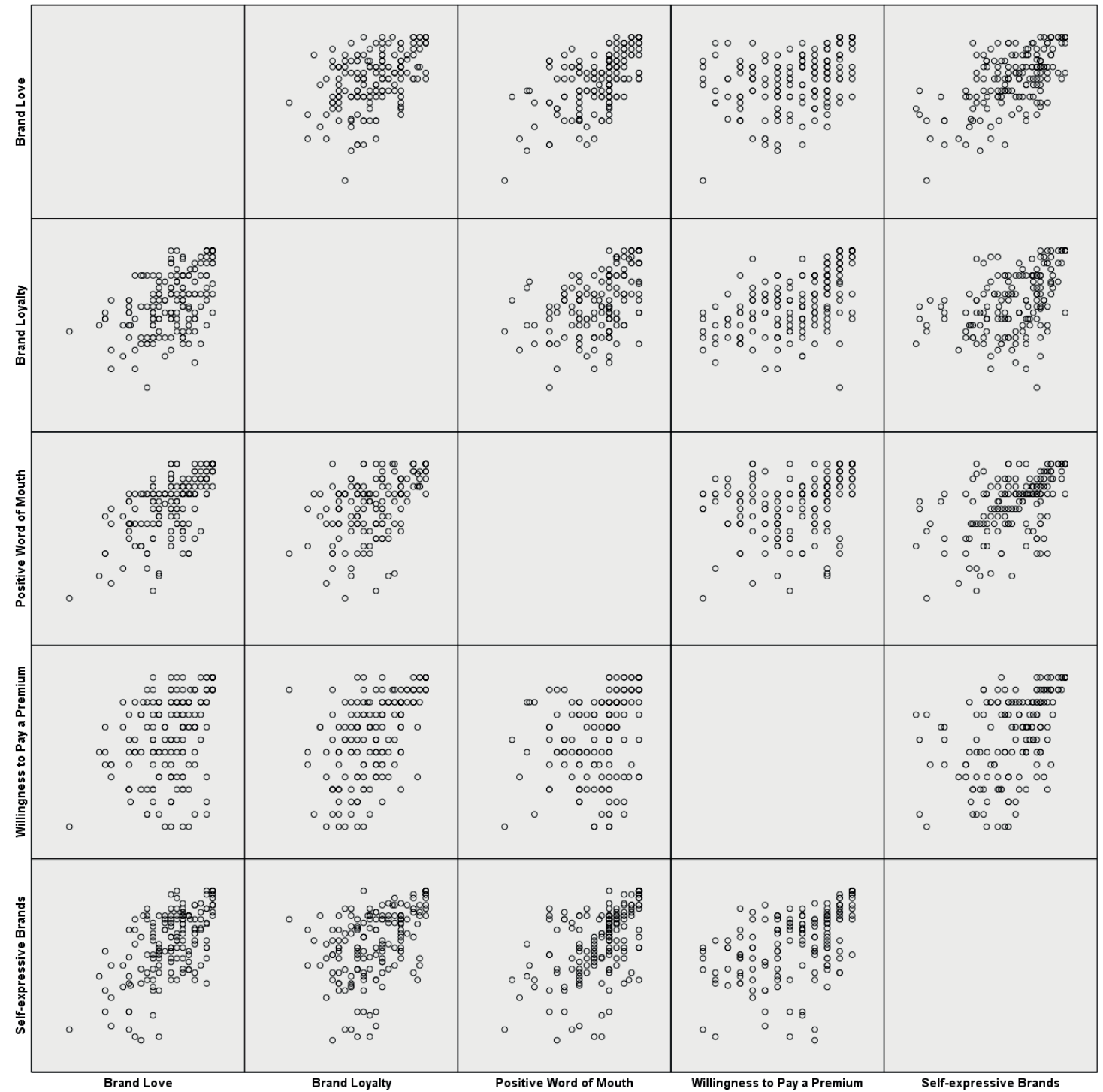

2: Scatterplots 


\section{RESULTS}

Good levels of internal consistency have been indicated by the results of Cronbach's alpha reliability testing. Aside of the scale 'willingness to pay a price premium', where one item was removed in order to improve the scale reliability, all other scales in the originally proposed items were kept, resulting in reliability scores between 0.642 and 0.912. Total scores were aggregated for each variable in order to form a composite variable and were used for further analysis. Five aggregate scores were generated as a result of the transformations. The aggregate scores were calculated as a mean of all the items incorporating the scale.

A Spearman's rank-order correlation was calculated to examine the existence and strength of monotonic relationships between self-expressive nature of luxury brands, brand love, brand loyalty, positive WOM and willingness to pay a price premium and is shown in Tab. III below. The basis for the correlations is the sample size of $n=164$ respondents with an exception of the correlations with the variable willingness to pay a premium (n = 163).

The results of the Spearman correlation show that luxury brands' self-expressive nature and brand love are strongly positively correlated, $\left(r=.604^{* *}, p<.001\right)$. It can also be seen that there was a moderate positive correlation between brand loyalty and self-expressive brands $(\mathrm{r}=.522 * *$, $\mathrm{p}<.001$ ), self-expressive brands and positive WOM $\left(\mathrm{r}=.562^{* *}, \mathrm{p}<.001\right)$, and self-expressive brands and willingness to pay a price premium $(\mathrm{r}=.562 * *$, $\mathrm{p}<.001$ ). The alternative hypotheses H1, H2, H3 and $\mathrm{H} 4$ are, therefore, accepted.

Brand love is strongly associated with positive word of mouth $(r=0.650, p<0.001)$. Moderate positive correlations are shown in statistically significant calculations between brand love and brand loyalty $(r=0.521, p<0.001)$ and brand love and willingness to pay a premium $(r=0.450, p<0.001)$. This leads to the conclusion the alternative hypotheses $\mathrm{H} 5, \mathrm{H} 6, \mathrm{H} 7$ are to be accepted.

The strength of relationships is graphically illustrated using the matrix of scatterplots displayed in Fig. 2.

\section{DISCUSSION}

The above discussed research replicated the findings of the original research conducted by Carroll and Ahuvia (2006) and the results confirm that brand love is strongly associated with the selfexpressive nature of brands.
Additional studies which claim that consumers select brands based on their personality and image (Ahuvia, 2005; Wallace et al., 2014) reflect the findings from the quantitative data showing that inner and social selves are positively correlated with brand love $(r=0.604, p<0.001)$ and the internal consistency of the scale is verified (7 items; alpha $=0.912$ ). As because the influence of a social self was only explored jointly with an inner self, it is not possible, within the current research, to confirm how much peer review and social status explain brand love. The qualitative data analyses show that consumers admit that brands become an important tool to establish and communicate their status within society although they may not recognize that the brands reflect their status within society. Being a collectivistic culture (Garg et al. 2015, p. 186) Indians are more likely to look for others' opinions and validation.

The model was adopted and extended by adding the construct of willingness to pay a price premium. As shown in Tab. III and graphically represented by Fig. 2, the resulting analyzed constructs show high correlations between .446 and .650. A factor analysis used on these constructs revealed, that the data could be better described within a three-factor model. The original factor of self-expressive brands (Carroll and Ahuvia, 2006) was complemented with two new factors. The first new factor merges the construct of brand love and positive WOM, suggesting that they present a common dimension. The other new factor combines brand loyalty and willingness to pay a price premium.

This three-factor structure (Fig. 3) might be used as an alternative model to adequately describe the relation between the analyzed constructs. Additional research carried out in other emerging markets and with larger samples is needed to proof this suggested new model.

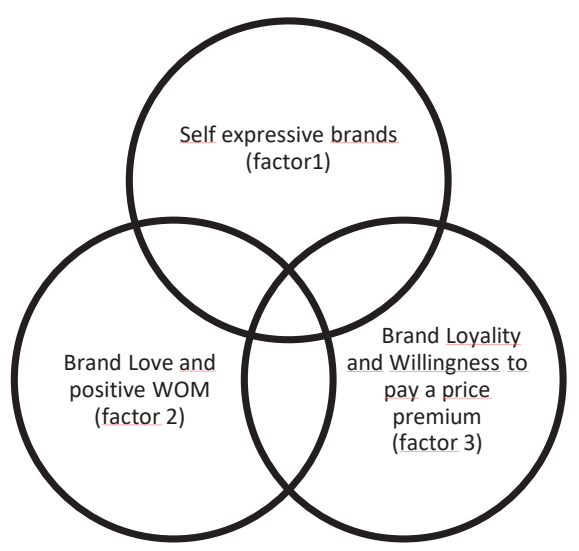

3: Three factor solution 


\section{CONCLUSION}

The results show a positive correlation between brand love, brand loyalty and the willingness to pay a price premium. The stronger association appears towards brand loyalty which is in line with findings from literature about the impact of brand love on loyalty (Batra et al., 2012). The research for the relationship between brand love and the willingness to pay a price premium is less extensive and the current research shows a moderate weak relation which may reflect the price sensitiveness of the Indian consumers. The link between positive word of mouth and brand love is also in line with other studies (e.g. Albert and Merunka, 2013) Being a part of a collectivist society Indian consumers positive WOM is a powerful tool to stimulate purchasing decisions.

By fostering brand love-based relationships with consumers' luxury brands can benefit from positive WOM of their brand ambassadors. The stronger the bonds towards the brands are, the easier it is to manage and monitor brand perceptions without additional marketing investments.

\section{REFERENCES}

AGGARWAL, P. 2004. The Effects of Brand Relationship Norms on Consumer Attitudes and Behavior. Journal of Consumer Research, 31(1): 87-101.

AHUVIA, A. 2005. Beyond the Extendet Self: Loved Objects and Consumers' Identity Narratives. Journal of Consumer Research, 32(1): 171-184.

ALBERT, N. and MERUNKA, D. 2013. The role of brand love in consumer-brand relationships. Journal of Consumer Marketing, 30(3): 258-266.

ALBERT, N., MERUNKA, D. and VALETTE-FLORENCE, P. 2008. When consumers love their brands: Exploring the concept and its dimensions. Journal of Business Research, 61(10): 1062-1075.

ALBERT, N., MERUNKA, D. and VALETTE-FLORENCE, P. 2009. The Feeling of Love Toward a Brand: Concept and Measurement. Advances in Consumer Research, 36: 300-307.

BAENA, V. 2016. Online and mobile marketing strategies as drivers of brand love in sports teams: Findings from Real Madrid. International Journal of Sports Sponsorship, 17(3): 202-218.

BATRA, R., AHUVIA, A. and BAGOZZI, R. P. 2012. Brand Love. Journal of Marketing, 76(2): 1-16.

CARROLL, B. A. and AHUVIA, A. C. 2006. Some antecedents and outcomes of brand love. Springer Science + Business Media Inc., 17: 79-89.

DELOITTE GLOBAL. 2018. Global Powers of Luxury Goods 2019. Deloitte.

FETSCHERIN, M. 2014. What type of relationship do we have with loved brands? Journal of Consumer Marketing, 31(6/7): 430-440.

FOURNIER, S. 1998. Consumers and their brands: developing relationship theory in consumer research. Journal of Consumer Research, 24(4): 343-373.

FRÖHLING, R. 2017. Markenliebe: Konzeption und empirische Untersuchung eines ganzheitlichen, kausalanalytischen Modells. Wuppertal: Springer Gabler Verlag.

HEGNER, S. M., FENKO, A. and TERAVEST, A. 2017. Using the theory of planned behaviour to understand brand love. Journal of Product and Brand Management, 26(1): 26-41.

HUANG, C.-C. 2017. The impacts of brand experiences on brand loyalty: mediators of brand love and trust. Management Decission, 55(5): 915-934.

ISMAEL, A. R. and SPINELLI, G. 2012. Effects of brand love, personality and image on word of mouth: The case of fashion brands among young consumers. Journal of Fashion Marketing and Management, 16(4): 386-398.

KAMAT, V. and PARULEKAR, A. A. 2007. Brand Love: The Precursor to Loyalty. In: PRIESTER, J. R., MACINNES, D. J. and PARK, C. W. (Eds.). Advertising and Consumer Psychology Conference, New Frontieers in Branding: Attitudes, Attachments, and Relationships. Santa Monica: Society for Consumer Psychology, pp. 94-97.

KARJAHUOTO, H., MUNNUKKA, J. and KIURU, K. 2016. Brand love and positive word of mouth: the moderating effects of experience and price. Journal of Product and Brand Management, 25(6): 527537.

KOTAK WEALTH MANAGEMENT. 2016. Top of the Pyramid India. Slide Share. [Online]. Available at: https://www.slideshare.net/TOPIndia/kotak-wealth-management-top-of-the-pyramid-indiaedition-2016 [Accessed: 2019, July 9].

MOUSSA, S. 2015. I may be a twin but I'm one of a kind: Are brand attachment and brand love different names for the same construct? Qualitative Market Reserach: An International Journal, 18(1): 69-85.

PINTO BORGES, A., CARDOSO, C. and RODRIGUES, P. 2016. Consumer's love for functional brands: the Aspirin case. International Journal of Pharmaceutical and Healthcare Management, 10(4): 477-491. 
ROSSITER, J. R. 2012. A new C-OAR-SE based content-valid and predictively valid measure that distinguishes brand love from brand liking. Marketing Letters, 23(3): 905-916.

SARKAR, A. 2014. Brand love in emerging market: a qualitative investigation. Qualitative Market Reserach: An International Journal, 17(4): 481-494.

SHIMP, T. A. and MADDEN, T. J. 1988. Consumer-Object Relations: A Conceptual Framework Based Analogously on Sternberg's Triangular Theroy of Love. Advances in Consumer Research, Volume, 15: 163-168.

STERNBERG, R. J. 1986. A Triangular Theory of Love. Psychological Review, 93(2): 119-135.

WALLACE, E., BUIL, I. and DE CHARNATONY, L. 2014. Consumer engagement with self-expressive brands: brand love and WOM outcomes. Journal of Product and Brand Management, 23(1): 33-42.

WALLACE, E., BUIL, I. and DE CHARNATONY, L. 2017. Consumers' self-congruence with a 'Liked' Brand: Cognitive network influence and brand outcomes. European Journal of Marketing, 51(2): 367-390.

WHANG, Y.-O., ALLEN, J., SAHOURY, N. and ZHANG, H. 2004. Falling in Love With a Product: the Strucuture of a Romantic Consumer - Product Relationship. Advances in Consumer Research, 31: 320-327.

YOO, B. and DONTHU, N. 2001. Developing and validating a multidimensional consumer-based brand equity scale. Journal of Business Research, 52(1): 1-14.

Maria Kostritsa: kostritsa.maria@gmail.com Hildegard Liebl: hildegard.liebl@fh-joanneum.at Rupert Beinhauer: rupert.beinhauer@fh-joanneum.at Jana Turčínková: jana.turcinkova@mendelu.cz 